\title{
Herpes simplex virus and cytomegalovirus reactivations among severe COVID-19 patients
}

\author{
Pierre Le Balc' $h^{1,2}$, Kieran Pinceaux ${ }^{1,2}$, Charlotte Pronier ${ }^{3}$, Philippe Seguin ${ }^{4}$, Jean-Marc Tadié ${ }^{1,2}$ and \\ Florian Reizine ${ }^{1,2^{*}}$ D
}

Dear Editor,

The SARS-CoV-2 infection can lead to severe acute respiratory distress syndrome (ARDS) with prolonged mechanical ventilation (MV). Patients with coronavirus disease 2019 (COVID-19) associated ARDS usually met the diagnosis criteria for sepsis-associated immunosuppression as acquired infections, primarily bacterial and fungal co-infections [1], are frequently encountered. Such secondary infections are associated with late mortality. Herpesviridae reactivation is common in nonimmunocompromised patients with prolonged MV and could be responsible for increased mortality and longer duration of MV in ICU $[2,3]$. Although the diagnosis of Herpesviridae pulmonary infection is challenging and not consensual in critically ill patients, therapeutic strategies are available to reduce morbidity and mortality [4]. As viral co-infections in these patients remain poorly investigated, we aimed to describe Herpesviridae pulmonary reactivations in patients with COVID-19 ARDS.

\section{Methods}

We reviewed all virology results for patients admitted to Rennes University Hospital (Rennes, France) for COVID-19 ARDS between March 3, 2020, and April 15, 2020. SARS-CoV-2 infection was confirmed by polymerase chain reaction (PCR). Patients mechanically ventilated longer than 7 days and who had negative PCR for herpes simplex virus (HSV) and cytomegalovirus (CMV) were included in the analysis. Herpes simplex virus and

\footnotetext{
* Correspondence: florian.reizine@chu-rennes.fr

'Service des Maladies Infectieuses et Réanimation Médicale, CHU Rennes, F-35033 Rennes, France

${ }^{2}$ Faculté de Médecine, Biosit, Université Rennes 1, F-35043 Rennes, France Full list of author information is available at the end of the article
}

cytomegalovirus replication were measured by quantitative real-time PCR on tracheal aspirates twice a week for each patient. Herpesviridae reactivation was defined as two consecutive positive HSV or CMV PCR on tracheal aspirates. The Mann-Whitney rank sum test was used to compare non-parametric continuous variables, and qualitative data were compared using Fisher's exact test. Statistical significance was defined as $P<.05$. PRISM version 8 (GraphPad Software, San Diego, CA, USA) was used to perform statistical analyses.

\section{Results}

A total of 38 patients were included. Table 1 shows the demographic, clinical, and biological characteristics of the included patients. The mean age was 59 years (interquartile range (IQR), 54-71), and $27(71 \%)$ were male. Of these 38 patients, 18 (47\%) presented at least one viral pulmonary reactivation. Nine patients had HSV reactivation alone, 2 presented CMV reactivation alone, and 7 had co-reactivation. Herpesviridae infection was diagnosed at a median of 9 days (IQR, 5-14). The median number of positive samples was 3 (IQR, 2-5).

Patients with Herpesviridae reactivation had significantly longer duration of MV compared with patients without Herpesviridae reactivation. Table 2 shows outcomes of patients according to Herpesviridae reactivation status.

\section{Discussion}

Our findings suggest that Herpesviridae reactivations are frequent in patients with COVID-19 ARDS, with higher rates than those described in previous studies performed in critically ill patients $[2,3]$. This result was expected since severe forms of COVID-19 ARDS are associated 
Table 1 ARDS COVID patient's characteristics at ICU admission

\begin{tabular}{|c|c|c|c|c|}
\hline & All patients $(n=38)$ & No Herpesviridae reactivation $(n=20)$ & Herpesviridae reactivation $(n=18)$ & $P$ value \\
\hline \multicolumn{5}{|l|}{ Demographic characteristics } \\
\hline Age, years & $59(54-71)$ & $57(48-69)$ & $64(55-72)$ & 0.07 \\
\hline \multicolumn{5}{|l|}{ Sex } \\
\hline Men & $27(71)$ & $15(75)$ & $12(67)$ & \multirow[t]{2}{*}{$>0.99$} \\
\hline Women & $11(29)$ & $5(25)$ & $6(33)$ & \\
\hline $\mathrm{BMI}$ & $24(24-31)$ & $27(23-27)$ & $26.9(24-29)$ & 0.78 \\
\hline Current smoking & $2(5)$ & $1(5)$ & $1(5)$ & 0.94 \\
\hline \multicolumn{5}{|l|}{ Coexisting conditions } \\
\hline Any & $19(50)$ & $10(50)$ & $9(50)$ & $>0.99$ \\
\hline Diabetes & $15(40.5)$ & $7(35)$ & $8(44)$ & 0.55 \\
\hline Cancer & $3(8)$ & $2(10)$ & $1(5)$ & $>0.99$ \\
\hline \multicolumn{5}{|c|}{ Clinical and biological baseline characteristics } \\
\hline White blood cell count $\left(10^{9} / \mathrm{L}\right)$ & $10.1(3.4-13)$ & $7.8(6-10.4)$ & $11.2(7.3-13.2)$ & 0.07 \\
\hline Lymphocyte count $\left(10^{9} / L\right)$ & $0.74(0.59-1.04)$ & $0.79(0.53-1.06)$ & $0.83(0.7-1.23)$ & 0.29 \\
\hline Ratio of $\mathrm{PaO}_{2}$ to $\mathrm{FiO}_{2}$ & $106(95-170)$ & $90(69-142)$ & $116(90-147)$ & 0.15 \\
\hline SAPS II score on day 1 & $42(31-58)$ & $39(29-61)$ & $42(33-55)$ & 0.65 \\
\hline SOFA score on day 1 & $3(2-7)$ & $7(2-9)$ & $3(2-7)$ & 0.81 \\
\hline
\end{tabular}

Table 2 Treatments and clinical course of COVID-19 patients according to Herpesviridae status

\begin{tabular}{|c|c|c|c|c|}
\hline & All patients $(n=38)$ & No Herpesviridae reactivation $(n=20)$ & Herpesviridae reactivation $(n=18)$ & $P$ value \\
\hline Antibiotics & $38(100)$ & $20(100)$ & $18(100)$ & 0.99 \\
\hline Antiviral & $32(84)$ & $16(80)$ & $16(89)$ & 0.66 \\
\hline Steroids & $12(32)$ & $4(20)$ & $8(44)$ & 0.16 \\
\hline ECMO & $3(8)$ & $1(5)$ & $2(11)$ & 0.49 \\
\hline Duration of NMB infusion & $6(3-11)$ & $5(3-8)$ & $6(3-11)$ & 0.73 \\
\hline Renal replacement therapy & $9(24)$ & $5(25)$ & $4(22)$ & 0.99 \\
\hline Prone positioning ventilation & $21(55)$ & $11(52)$ & $10(56)$ & 0.24 \\
\hline Duration of mechanical ventilation & $18(13-25)$ & $9(6-14)$ & $23(18-39)$ & 0.0001 \\
\hline Ventilator-free days at day 28 & $8(0-15)$ & $14(7-20)$ & $2(0-3)$ & 0.0008 \\
\hline Ratio of $\mathrm{PaO}_{2}$ to $\mathrm{FiO}_{2}$ on day 7 & $193(135-248)$ & $212(160-260)$ & $178(135-195)$ & 0.04 \\
\hline Ratio of $\mathrm{PaO}_{2}$ to $\mathrm{FiO}_{2}$ on day 14 & $216(174-308)$ & $280(222-401)$ & $186(114-233)$ & 0.01 \\
\hline SOFA score on day 7 & $7(5-11)$ & $7(5-10)$ & $10(6-11)$ & 0.19 \\
\hline SOFA score on day 14 & $7(2-10)$ & $3(1-10)$ & $7(2-10)$ & 0.39 \\
\hline Bacterial VAP & $9(24)$ & $3(15)$ & $6(33)$ & 0.18 \\
\hline ICU length of stay & $23(16-34)$ & $16(12-24)$ & $29(24-47)$ & 0.0001 \\
\hline Death in ICU & $4(10.5)$ & $2(10)$ & $2(11)$ & 0.99 \\
\hline
\end{tabular}

Data are presented as median (IQR: interquartiles), $n$ (\%). $P$ values comparing the Herpesviridae reactivation and no Herpesviridae reactivation groups are tested by the Mann-Whitney (continuous variables) or Fisher's exact test (categorical variables)

Abbreviations: ECMO extracorporeal membrane oxygenation, $\mathrm{NMB}$ neuromuscular blockade, $\mathrm{PaO}_{2}$ arterial oxygen tension, FiO ${ }_{2}$ fraction of inspired oxygen, SOFA Sequential Organ Failure Assessment, VAP ventilator-associated pneumonia, ICU intensive care unit 
with biological and clinical markers of acquired immunosuppression such as lymphopenia [1]. This state of immunodeficiency probably plays a role in the occurrence of viral reactivations.

Among the most frequent risk factors for CMV and HSV reactivation in the ICU patients, sepsis and prolonged MV have been described in several studies $[5,6]$. COVID-19 patients develop typical clinical and biological manifestations of septic shock [1]. There is no clear evidence that Herpesviridae reactivations induce difficulties to wean patients from MV nor increase the length of stay in COVID-19 patients, and our sample size did not allow us to perform a multivariate analysis. Larger studies are needed to explore such association. However, previous observational studies $[5,6]$ showed that Herpesviridae detection in the lower respiratory tract is associated with poorer outcomes.

Finally, our results suggest that SARS-CoV-2 infection could be a risk factor for Herpesviridae reactivation. Rapid identification of these co-infections seems warranted as it may impact the prognosis of infected patients. However, the direct consequences and the usefulness of antiviral treatments for these Herpesviridae infections remain factors that deserve to be investigated.

\section{Acknowledgements}

None

\section{Authors' contributions}

PLB, KP, PS, JMT, and FR took care of the patients, performed the literature review, and wrote the first draft of the article. CP performed the diagnostic tests and raised the critical comments on the article. The authors read and approved the final manuscript.

\section{Funding}

This work was supported by the CFTR ${ }^{2}$ (Covid Fast Track Research Rennes) institutionnal grant from Rennes Univesitary Hospital.

Availability of data and materials

The datasets from this study are available from the corresponding author on request.

Ethics approval and consent to participate

The study was approved by Rennes University Hospital's review board (no. 16-117).

\section{Consent for publication}

Not applicable

\section{Competing interests}

The authors report no conflict of interest related to this work.

\section{Author details}

'Service des Maladies Infectieuses et Réanimation Médicale, CHU Rennes, F-35033 Rennes, France. 'Faculté de Médecine, Biosit, Université Rennes 1 F-35043 Rennes, France. ${ }^{3}$ Service de Virologie, CHU Rennes, F-35033 Rennes, France. ${ }^{4}$ Service de Réanimation Chirurgicale, CHU Rennes, F-35033 Rennes, France.
Received: 14 July 2020 Accepted: 12 August 2020

Published online: 28 August 2020

\section{References}

1. Chen N, Zhou M, Dong X, Qu J, Gong F, Han Y, et al. Epidemiological and clinical characteristics of 99 cases of 2019 novel coronavirus pneumonia in Wuhan, China: a descriptive study. Lancet. 2020;395(10223):507-13.

2. Luyt C-E, Combes A, Deback C, Aubriot-Lorton M-H, Nieszkowska A, Trouillet $J$-L, et al. Herpes simplex virus lung infection in patients undergoing prolonged mechanical ventilation. Am J Respir Crit Care Med. 2007;175(9): 935-42.

3. Chiche L, Forel J-M, Roch A, Guervilly C, Pauly V, Allardet-Servent J, et al. Active cytomegalovirus infection is common in mechanically ventilated medical intensive care unit patients*. Crit Care Med. 2009;37(6):1850.

4. Schuierer L, Gebhard M, Ruf H-G, Jaschinski U, Berghaus TM, Wittmann M, et al. Impact of acyclovir use on survival of patients with ventilatorassociated pneumonia and high load herpes simplex virus replication. Crit Care. 2020;24(1):12.

5. Coisel Y, Bousbia S, Forel J-M, Hraiech S, Lascola B, Roch A, et al. Cytomegalovirus and herpes simplex virus effect on the prognosis of mechanically ventilated patients suspected to have ventilator-associated pneumonia. PLoS One. 2012:7(12) [cited 2020 Jun 26]. Available from: https://www.ncbi.nlm.nih.gov/pmc/articles/PMC3517464/.

6. Al-Omari A, Aljamaan F, Alhazzani W, Salih S, Arabi Y. Cytomegalovirus infection in immunocompetent critically ill adults: literature review. Ann Intensive Care. 2016;6 [cited 2020 Jun 26]. Available from: https://www.ncbi. nlm.nih.gov/pmc/articles/PMC5095093/.

\section{Publisher's Note}

Springer Nature remains neutral with regard to jurisdictional claims in published maps and institutional affiliations.
Ready to submit your research? Choose BMC and benefit from:
- fast, convenient online submission
- thorough peer review by experienced researchers in your field
- rapid publication on acceptance
- support for research data, including large and complex data types
- gold Open Access which fosters wider collaboration and increased citations
- maximum visibility for your research: over $100 \mathrm{M}$ website views per year
At BMC, research is always in progress.
Learn more biomedcentral.com/submissions 